\title{
Pelaksanaan Sistem Bagi Hasil Pada Gadai Sawah Antara Penggadai Dan Penggarap di Desa Patampanua Kecamatan Matakali Kabupaten Polewali Mandar Wahyuni, Busrah
}

Prodi Hukum Ekonomi Syariah, Fakultas Agama Islam, Universitas Al Asyariah Mandar wahyuni072690@gmail.com

\begin{abstract}
Abstrak
Tujuan penelitian ini ialah untuk: 1) Megetahui sistem bagi hasil gadai sawah yang terjadi antara penggadai dan penggarap di Desa Patampanua Kecamatan Matakali. 2) Megetahui pandangan hukum islam mengenai sistem bagi hasil gadai sawah yang terjadi antara penggadai dan penggarap di desa Patampanua kecamatan Matakali. Jenis penelitian ini menggunakan jenis penelitian kualitatif yang menggunakan pendekatan deskriptif kualitatif. Sumber data yang digunakan adalah sumber data primer dan sekunder. Kemudian teknik pengumpulan data dilakukan dengan cara wawancara dan dokumentasi. Penelitian ini bersifat deskriptif yang dimana penelitian deskriptif kualitataif yaitu analisis harus dilakukan secara terus-menerus agar data yang diperoleh baik melalui wawancara dan dokumen-dokumen sehingga dapat menghasilkan kesimpulan yang kongret dan vailid. Hasil penelitian menujukkan bahwa sistem bagi hasil gadai sawah antara penggadai dan penggarap sawah yang ada di Desa Patampanua didasarkan pada tradisi masyarakat dengan membagi hasil dengan rata (penggadai dan penggarap) dan bagi hasil satu banding dua (satu untuk penggadai dan dua untuk penggarap) dan hal tersebut sudah berlangsung sejak lama. Dalam pandangan hukum islam sendiri sistem bagi hasil tersebut tidak dilarang selama tidak ada dalil yang melarangnya dan dalam akadnya tidak terdapat hal yang fasid serta tidak melanggar konsep moral Islam dalam hal bagi hasil sehingga tercipta kerja sama yang dapat saling menguntungkan satu sama lain tanpa merugikan salah satu pihak mana pun. Bila dijalankan sesuai dengan aturan bagi hasil itu sendiri maka dapat mendatangkan kemakmuran bagi kehidupan dengan cara yang benar dan di ridhoi oleh Allah SWT.
\end{abstract}

Kata kunci: Bagi hasil, gadai sawah, penggadai, penggarap.

\begin{abstract}
The objectives of this study are to: 1) Know the profit sharing system for pawning the fields that occurs between the pawnbroker and the tenant in Patampanua Village, Matakali District. 2) Knowing the views of Islamic law with respect to the benefit sharing framework for pawning the fields that occurred between the pawnbroker and the tenant in Patampanua village, Matakali subdistrict. This type of research uses a qualitative type of research that uses a subjective engaging methodology. Wellsprings of information utilized are essential and auxiliary information sources. Then at that point the information assortment technique is done by interview and documentation. This research is descriptive in which qualitative descriptive research, namely the analysis must be carried out continuously so that the data obtained through interviews and documents can produce concrete and valid conclusions. results of the study show that the profit-sharing system for pawning the fields between the pawnbrokers and cultivators in Patampanua Village is based on the community tradition by dividing the results equally (the pawnbroker and the cultivator) and the profit sharing is one to two (one for the pawn and two for the cultivator). this has been going on for a long time. In the view of Islamic law itself, the profit-sharing system is not prohibited as long as there is no evidence that prohibits it and in the contract there are no fasid things and does not violate the Islamic moral concept in terms of profit-sharing so as to create cooperation that can benefit each other without harming one another. any party. If it is carried out in accordance with the rules of profit sharing itself, it can bring prosperity to life in the right way and is blessed by Allah SWT.
\end{abstract}

Keywords: Profit sharing, field pawning, pawnbrokers, cultivators. 


\section{PENDAHULUAN}

Manusia merupakan makhluk sosial yang mempunyai kodrat hidup dalam masyarakat. Sebagai makhluk sosial dalam hidupnya manusia memerlukan adanya manusia lain untuk saling melengkapi dan juga bisa hidup bersama di arena publik. Dalam aktivitas publik, orang secara konsisten berhubungan satu sama lain jika mereka memahaminya untuk memenuhi kebutuhan mereka dan aktivitas publik di mana setiap orang melakukan aktivitas yang sebanding dengan orang lain disebut muamalah.

Muamalah secara konsisten dan terus berkembang namun penting untuk diperhatikan agar peningkatan tersebut tidak menimbulkan tantangan hidup bagi jamaah tertentu yang disebabkan oleh faktor tekanan atau keruwetan dari perkumpulan yang berbeda karena terkadang dalam hidup seseorang mengalami kesulitan dalam segala hal. sekaligus Tantangan yang dihadapi bergeser sehingga individu sangat membutuhkan bantuan satu sama lain. Di antara tantangan yang berbeda masalah yang dilihat oleh seseorang adalah saat dia tidak memiliki uang tunai. ${ }^{1}$

Islam adalah agama yang memberikan aturan bagi keberadaan manusia secara keseluruhan Islam juga merupakan agama yang total dan indah yang telah menetapkan standar dasar di semua bagian keberadaan manusia baik dalam cinta maupun muamalah (hubungan antar hewan) itulah alasan mengapa sangat penting bagi kita untuk mengetahui prinsip-prinsip Islam di semua bagian kehidupan kita sehari-hari termasuk hubungan sosial dengan orang-orang khususnya mengenai pertukaran properti dimulai dengan satu tangan kemudian ke tangan berikutnya. Manusia adalah makhluk sosial yang hidup di mata publik Sebagai makhluk sosial Anda dapat melakukan berbagai pendekatan untuk memenuhi kebutuhan hidup salah satunya adalah dengan memanfaatkan gadai (rahn). Pokok pikiran gadai adalah pinjam meminjam antara pihak yang membutuhkan harta kepada orang yang mempunyai kelebihan harta dengan menggadaikan barang yang dimilikinya sebagai jaminan sebagai penopang kepercayaan kepada pihak yang meminjamkan uang hak gadai adalah hubungan yang sah antara seseorang dengan tanah yang mempunyai tempat dengan orang lain yang telah mendapat uang yang dijanjikan dari besarnya dan selama uang itu belum dikembalikan, tanah yang dimaksud dibatasi oleh pihak yang memberikan hak gadai tunai (pemegang gadai). ${ }^{2}$

Padahal Nabi Muhammad SAW telah mencontohkan model pembiayaan yang saat ini dalam kerangka moneter syariah yang dikenal dengan pembiayaan mudharabah. Model pembiayaan Nabi Muhammad SAW ini dipandang sebagai kerangka simpanan modal khususnya ketika beliau dipercaya untuk menyampaikan beberapa produk Siti Khadijah r.a. dari Mekah ke tempat yang terkenal negeri syam kemudian produk tersebut dijadikan modal usaha oleh Nabi untuk ditukarkan dan hasil yang dibeli produk lain untuk dijual kembali di pasar Bushra di tempat yang terkenal tersebut Setelah beberapa waktu Nabi kembali ke Mekah dengan hasil dari usahanya dan mengumumkannya kepada Siti Khodijah r.a. Sumber daya yang telah dibuat harus ditentukan dan dikontraskan dan sumber daya pertama harta yang pertama dikembalikan kepada pemiliknya, sedangkan hasilnya dibagi antara pemilik harta (rabbul maal) dan orang yang mengawasinya (mudharib) sebagaimana ditunjukkan oleh kesepakatan diawal. ${ }^{3}$

${ }^{1}$ Ahmad Affan Ghafar," Pemanfaatan Barang Gadai Dalam Perjanjian Hutang Dibawah Tangan”, Jurnal Studi Kenotariatan, vol.12 no1 (2019):h.2

2Imamil Muttaqin," Perspektif Hukum Islam Terhadap Pelaksanaan Gadai Sawah Dalam Masyarakat Desa Dadapayam Kecamatan Suruh Kabupaten Semarang”, Kearsipan Fakultas Agama Islam Universitas Muhammadiyah Surakarta, 2015, hal 1

${ }^{3}$ Umrotul Khasanah," Sistem Bagi Hasil Dalam Syariat Islam”, Jurnal Hukum dan Syariah, vol 1 no.2 (2009):h.120 
Tanah juga signifikan dalam perekonomian. Tanah dapat mengatasi masalah untuk tempat tinggal dikembangkan atau dikerjakan dan item dalam tindakan finansial. Orang-orang di daerah perkotaan akan lebih banyak menggunakan tanah untuk tempat tinggal atau barang-barang dalam hal keuangan dari pada untuk bekerja sementara penduduk setempat umumnya menggemburkan tanah dengan menanam hasil panen untuk dituai. Dalam praktek sistem pertanian khususnya dalam hal gadai yang berlaku di kalangan masyarakat berfluktuasi walaupun secara struktur berbeda tapi terdapat kesamaan dalam pelaksanaannya terutama dalam hal hak dan kewajiban antara pengusaha dan buruh atau antara pemilik modal dan buruh.

Kemudian yang jadi persoalan adalah sistem bagi keuntungan yang dilaksanakan oleh pemilik modal dan pekerja itulah masih diragukan terkait kesesuaiannya yang bisa saja melenceng dari hukum Islam.

Berdasarkan latar belakang diatas yang telah dipaparkan mengenai pelaksanaan sistem pembagian keuntungan yang dilakukan dengan menggadaikan sawah yang berlaku secara lokal. Sejalan dengan ini, penulis memberikan judul untuk masalah ini yaitu "Pelaksanaan Sistem Bagi Hasil Pada Gadai Sawah Antara Penggadai dan Penggarap Sawah di Desa Patampanua Kecamatan Matakali”.

\section{METODE PENELITIAN}

Penelitian ini menggunakan penelitian kualitatif. Pada dasarnya penelitian kualitatif dilaksanakan dalam keadaan alamiah (natural setting) dan data yang dikumpulkan umumnya bersifat kualitatif. ${ }^{4}$ Penelitian ini termasuk penelitian terjadi dilapangan dengan sifatnya yang menggambarkan mengenai suatu permasalahan. ${ }^{5}$ Lokasi penelitian ini bertempat di Desa Patampanua Kecamatan Matakali. Adapun pendekatan penelitian yaitu pendekatan social dan pendekatan syar'i. Sumber informasi dari eksplorasi ini adalah data primer dan sekunder. Teknik pengumpulan informasi yang digunakan dalam penelitian ini yaitu observasi, wawancara dan dokumentasi. Instrumen yang diperlukan didalam penelitian ini adalah pedoman wawancara, buku catatan dan handphone atau kamera. Teknik pengolahan dan analisis data dilakukan dengan cara menjelaskan subyektif, khususnya dengan membedah wawancara, dokumentasi dan observasi. Dalam teknik eksplorasi ini penulis berusaha untuk memperkenalkan realitas sasaran yang ditunjukkan oleh kondisi dan keadaan yang benar-benar terjadi pada saat penelitian dilakukan. ${ }^{6}$

\section{HASIL PENELITIAN}

\section{A. Praktek Sistem Bagi Hasil Gadai Sawah Antara Penggadai Dan Penggarap Sawah Di Desa Patampanua Kecamatan Matakali}

Dalam Islam, gadai berasal dari kata Arab al-rahn yang berarti tetap (al-tsubut wa aldawam) misalnya kata ma'rakid artinya air yang diam dan tergenang. ${ }^{7}$ Adapun menurut istilah, rahn berarti menjadikan harta sebagai jaminan utang (ja'l al-mal watsiqah bi dayn). ${ }^{8}$

\section{h.161}

${ }^{4}$ Harbani Pasolong, Metode Penelitian Administrasi Publik, (Bandung: Alfabeta, 2013)

${ }^{5}$ Imam Suprayogo dan Tobroni, Metodologi Penelitian Sosial-Agama, (Bandung: Rosdakarya, 2001), h. 9.

${ }^{6}$ Ade Tri Cahyani, "Tinjauan Hukum Islam Terhadap Peraktik Gadai Pada Masyarakat Kecamatan Tapos Kota Depok", Kearsipan Fakultas Syariah dan Hukum UIN Syarif Hidayatullah Jakarta, 2015, hal 4.

${ }^{7}$ Idri, Hadis Ekonomi, (Depok: Kencana, 2015). h. 197 
Sementara itu, seperti yang ditunjukkan oleh Sabiq, rahn adalah barang yang memiliki nilai sumber daya menurut syara' sebagai jaminan hutang sehingga orang yang bersangkutan dapat mengambil suatu kewajiban atau dia dapat mengambil sedikit (manfaat) dari barang-barang tersebut. ${ }^{9}$ Kesepakatan ini ditemukan dalam peraktek bahwa, jika seseorang perlu berutang kepada orang lain ia menjadikan hartanya sebagai jaminan baik harta yang tak hidup atau binatang peliharaan yang sangat dipengaruhi oleh pemberi pinjaman sampai peminjam membayar komitmennya.

Pada dasarnya sistem bagi hasil gadai sawah antara penggadai dan penggarap yang terjadi di Desa Patampanua merupakan sistem bagi hasil gadai yang dilakukan secara turun temurun sesuai dengan tradisi akad gadai yang sudah berlangsung sejak lama. Dengan demikian, sistem bagi hasil gadai yang berjalan di Desa Patampanua ini tidak pernah ditemukan konflik akibat dari sistem bagi hasil yang dilakukan sesuai dengan tradisi yang dimana dari hal tersebut sistem bagi hasil gadai sawah di Desa Patampanua ini tidak pernah berubah hingga saat ini.

Dari hasil penelitian, penulis menemukan dua sistem bagi hasil gadai sawah yang terjadi di Desa Patampanua yaitu:

1. Bagi Hasil Gadai Sawah dengan Rata Antara Penggadai Dan Penggarap.

Adapun hasil wawancara dari beberapa masyarakat di Desa Patampanua terkait dengan sistem bagi hasil gadai sawah antara penggadai dan penggarap sawah yang berlangsung dikalangan masyarakat sebagimana yang dinyatakan oleh toko masyarakat di Desa Patampanua sebagai berikut:

"Sistem bagi hasil gadai sawah yang terjadi di desa ini merupakan sistem bagi hasil yang sejak dahulu sudah dilakukan oleh masyarakat di Desa Patampanua hingga saat ini. Terkait sistem bagi hasil gadai sawah antara penggadai dan penggarap didesa ini biasanya di lakukan dengan membagi rata hasil penen antara penggadai dan penggarap kemudian menanggung bersama biaya perawatan sawah tersebut sampai pada masa panen, begitu pula untung ruginya akan di tanggung bersama". ${ }^{10}$

Dari sistem bagi hasil gadai sawah di Desa Patampanua ini dapat di pahami bahwa sistem pembagian hasil panen antara penggadai dan penggarap tergantung pada perjanjian dan kesepakatan diawal sebelum dilakukannya kerja sama. Terkait untung atau ruginya dari hasil penen sawah yang digadai oleh penggadai akan di tanggung oleh kedua belah pihak sehingga tidak akan ada pihak yang merasa dirugikan.

Adapun hasil pengamatan penulis, sistem bagi hasil gadai sawah dengan rata tersebut terjadi atas kesepakatan kedua belah pihak (penggadai dan penggarap) dan merupakan sistem bagi hasil dengan resiko kerugian yang rendah karena modal dan untung rugi di tanggung bersama.

Selanjutnya hasil wawancara penulis dengan salah seorang yang melakukan peraktik gadai selaku penggadai dan penggarap di Desa Patampanua yang menuturkan bahwa:

"Jika saya mengadai sebidang lahan sawah dari seseorang sedang saya tidak dapat menggarapnya sendiri maka saya meminta pada pemilik sawah yang saya gadai atau pada orang lain untuk menggarap sawah tersebut dan jika salah satu diantara mereka

${ }^{8}$ Mahmud'Abd. al-Rahman'Abd al-Mun'im, Mu'jam al-Musthalahat wa al-Alfazh alFiqhiyyah, juz II ( Kairo: Dar al-Fadhilah, 2008 M.) hlm. 189.

${ }^{9}$ Abdul Ghofur Ansori, Gadai Syariah di Indonesia, Konsep, Implementasi dan Intitusional, Gadjah Madaa University PRESS, 2006. Cet, ke-1, hal.88

${ }^{10}$ Yono, Toko Masyarakat Desa Patampanua, Kec. Matakali Kab. Polman, Sulbar, Wawancara oleh penulis di Patampanua, 12 Mei 2021 
menyetujuinya maka saya akan membuat kesepakatan diawal dengan penggarap mengenai bagi hasil penen dari sawah yang saya gadai tersebut sehingga bila tiba masa panen pembagian hasilnya sudah jelas". 11

"Bila saya (penggarap) dan penggadai memutuskan untuk melakukan bagi hasil gadai sawah secara rata maka biaya selama masa perawatan dari sawah lahan tersebut akan kami tanggung bersama seperti pupuk, dompeng dan keperluan perawatan lahan sawah lainnya sampai masa penen tiba dan setelah masa penen tiba maka keseluruhan hasil penen akan kami (penggarap dan penggadai) bagi rata dengan seadil-adilnya". ${ }^{2}$

Dari hasil wawancara penulis dengan penggadai dan penggarap sawah tersebut bahwa selama pembagian hasil panen sawah yang digadai oleh penggadai sesuai dengan kesepakatan diawal maka tidak akan timbul masalah dari kedua bela pihak (penggadai dan penggarap) karena hasil keputusan bagi hasil panen sawah gadian tersebut merupakan kesepakatan atas dasar suka sama suka.

Hasil pengamatan penulis terkait penetapan bagi hasil gadai sawah diawal kesepakatan seperti yang terjadi dilapangan semata-mata untuk menghidari konflik saat tiba masa penen, dengan kejelasan sistem bagi hasil yang akan di gunakan maka tidak akan terjadi perseteruan disaat pembagian hasil penen tersebut.

Islam hanya menganggap sah hubungan kerja sama yang berdasarkan prinsip keadilan dan kesepakatan bersama, tanpa ada penindasan dan keterpaksaan dari kedua belah pihak yang masing-masing berhak menikmati kebebasan dan persamaan secara penuh terhadap hak-hak mereka sebagaimana kewajiban mereka untuk menjalani hubungan timbale balik yang harmonis saling memberi dan menerima.

2. Bagi Hasil Gadai Sawah Dengan Sistem Satu Banding Dua Antara Penggadai Dan Penggarap.

Berikut hasil wawancara penulis dengan toko masyarakat terkait sistem bagi hasil gadai sawah antara penggadai dan penggarap yaitu:

"Kemudian sistem bagi hasil gadai sawah satu banding dua (satu untuk penggadai dan dua untuk penggarap) dilakukan dengan memberi bagian lebih banyak hasil penen sawah kepada penggarap dibanding dengan hasil panen yang diterima oleh penggadai akan tetapi penggaraplah yang akan menanggung biaya perawatan sawah tersebut sampai pada masa panen tiba dan dari hal ini penggarap bisa saja merugi bila harga gabah turun sedang biaya perawatan harus tetap ditanggung olehnya". ${ }^{13}$

Dari wawancara diatas dapat dilihat secara jelas bahwa sistem bagi hasil gadai sawah seperti ini cenderung memiliki resiko kerugian yang sangat tinggi bagi penggarap sendiri dan bisa saja sebaliknya menjadi untung lebih banyak bila harga gabah sedang naik di karenakan penggaraplah yang mendapat bagian hasil panen sawah lebih banyak.

Hasil pengamatan penulis terkait sistem bagi hasil gadai satu banding dua yang terjadi di lapangan memang lebih berat bagi penggarap akan tetapi kesepakatan seperti ini tidak akan terjadi tanpa persetujuan dari kedua bela pihak (penggadai dan penggarap) menginginkannya.

Adapun tanggapan Nono selaku penggarap terkait dengan bagi hasil gadai sawah dengan sistem satu banding dua yang menyatakan bahwa:

${ }^{11}$ Riswan, Penggadai Desa Patampanua, Kec. Matakali Kab. Polman, Sulbar, Wawancara oleh penulis di Patampanua, 12 Mei 2021

${ }^{12}$ Adi, Penggarap Sawah Desa Patampanua, Kec. Matakali Kab. Polman, Sulbar, Wawancara oleh penulis di Patampanua, 13 Mei 2021

${ }^{13}$ Yono, Toko Masyarakat Desa Patampanua, Kec. Matakali Kab. Polman, Sulbar, Wawancara oleh penulis di Patampanua, 12 Mei 2021 
"Bila hasil penen sawah gadaian yang saya garap ini dibagi dengan sistem satu banding dua dan hasil panennya sebanyak 10 karung, maka penggadai yang menunjuk saya (penggarap) untuk menggarap sawah yang digadainya ini akan mendapat bagian empat karung sedang saya (penggarap) akan mendapat enam karung dengan ketentun saya (penggarap) yang harus menanggung semua biaya selama masa perawatan sawah gadaian ini". ${ }^{14}$

Dari hasil temuan diatas dapat dipahami dalam sistem pembagian keuntungan gadai sawah ini penggaraplah yang mendapat bagian terbanyak dibanding dengan penggadai akan tetapi biaya selama masa perawatan sawah tersebut akan ditanggung oleh penggarap itu sendiri.

Dalam hal pembagian hasil gadai sawah seperti ini menurut penulis bisa saja akan menguntungkan dan memberatkan si penggarap apabilah harga gabah sedang naik maka penggarapkan akan dapat banyak keuntungan kerena memiliki lebih banyak bagian sedangkan jika harga gabah turun maka penggarapkan akan merugi karena penggaraplah yang harus menanggung biaya perawatan sawah gadian yang digarapnya sedang biaya perawatan tersebut tidak berubah dan bisa saja akan menjadi lebih mahal.

Dari kedua sistem bagi hasil gadai sawah yang dilakukan oleh masyarakat Dasa Patampanua tersebut penulis menemukan sisi untung rugi yang berbeda. Namun untung menghindari kerugian yang lebih besar antara kedua belah pihak (penggadai dan penggarap) maka sistem bagi hasil yang akan doniman dilakukan adalah sistem bagi hasil gadai secara rata karena segala resiko dan keuntungan akan ditanggung oleh kedua belah pihak.

Kemudian penulis juga melakukan wawancara dengan seorang penggarap dan penggadai mengenai kesepakatan dari sistem bagi hasil gadai sawah yang menyatakan bahwa:

"Bila pembagian hasil gadai sawah dibagi sesuai dengan kesepakatan diawal dan dilakukan dengan seadil-adilnya, maka saya sebagai penggarap tidak akan masalah karena untung rugi dari sawah yang saya garap akan saya tanggung bersama dengan penggadai sawah tersebut". 15

"Selama ini kesepakatan yang saya lakukan dengan penggarap sawah yang saya gadai hanya melalui lisan tanpa menggunakan hitam diatas putih (surat perjanjian) dan tanpa saksi. sehingga kesepakatan tersebut bisa saja berubah sewaktu-waktu Apabila kesepakatan awal pembagian hasil panen sawah yang saya gadai di bagi rata dengan penggarap, bisa saja pembagiannya berubah menjadi satu banding dua (satu untuk penggadai dan dua untuk penggarap) hal ini terjadi apabilah ada salah satu pihak di antara kami (penggadai dan penggarap sawah) merasa tidak adil dari segi pembagian hasil panen sawah gadian dan hal tersebut merupakan hal lumrah yang terjadi dikalangan kami (masyarakat Desa Patampanua)". ${ }^{16}$

Dari hasil wawancara penulis dengan salah satu penggadai diatas maka dapat dipahami bahwa kesepakatan yang terjadi antara penggadai dan penggarap sawah hanya menggunakan lisan akan tetapi dalam kesepakatan tersebut sudah dijelaskan lebih detail terkait pembagian hasil panennya apakah akan dibagi rata atau dibagi dengan perbandingan satu banding dua. Sehingga

\footnotetext{
${ }^{14}$ Nono, Penggarap Sawah Desa Patampanua, Kec. Matakali Kab. Polman, Sulbar, Wawancara oleh penulis di Patampanua, 13 Mei 2021

${ }^{15}$ Darwis, Penggarap Sawah Desa Patampanua, Kec. Matakali Kab. Polman, Sulbar, Wawancara oleh penulis di Patampanua, 12 Mei 2021

${ }^{16}$ Nawang, Penggadai Desa Patampanua, Kec. Matakali Kab. Polman, Sulbar, Wawancara oleh penulis di Patampanua, 12 Mei 2021
} 
dengan hal tersebut dapat meminimalisir terjadinya konflik di antara mereka (penggadai dan penggarap sawah) dalam segi pembagian hasil panen sawah gadian.

Dan dari hasil wawancara diatas juga menyatakan bahwa kesepakatan bagi hasil yang mereka (penggadai dan penggarap sawah) buat bisa saja berubah sewaktu-waktu apabila ada salah satu pihak yang merasa tidak adil dalam segi pembagian hasil panen sawah gadian tersebut dan perubahan kesepakatan bagi hasil ini bisa saja terjadi apabila kedua belah pihak menyetujui perubahan tersebut.

Adapun hasil pengamatan penulis bisa jadi dari penulis yang diarahkan pada sistem bagi hasil gadai sawah yang dilakukan oleh sebagian masyarakat di Desa Patampanua ini tidak ditemukan penyimpangan dari segi sistem keuntugan gadai sawah yang terjadi pada penggadai dan penggarap sawah karena kesepakatan bagi hasil panen dibuat secara detail diawal kemudian dilakukan secara lisan atas dasar suka sama suka sehingga tidak ada pihak yang merasa dirugikan.

\section{B. Pandangan Hukum Islam Mengenai Sistem Bagi Hasil Gadai Sawah Antara Penggadai Dan Penggarap Di Desa Patampanua Kecamatan Matakali}

Sistem bagi hasil gadai sawah yang adadi masyarakat Desa Patampanua terdapat dalam hukum Islam terkait kerja sama dalam hal bagi hasil gadai sawah yang dilakukan oleh penggadai dan penggarap. Dalam perjanjian bagi hasil gadai sawah tidak ditemukan penyimpangan dimana tidak ada pihak satu pun yang merasa dirugikan karena perjanjian bagi hasil yang dibuat oleh kedua pihak (penggadai dan penggarap) dilakukan atas dasar kemauan mereka sendiri.

Gadai adalah transaksi antara orang yang menggadaikan dan penggadai dengan bahasa lain antara pemberi hutang dan pemilik sawah. Dimana pemilik sawah menggadaikan sawahnya kepada sang pemilik dengan kesepaktan uang tersebut akan pulangkan ke penerima gadai dalam jangka waktu sesuai dengan kesepakatan pada saat akan dilakukan. Dengan catatan bahwa pengelolahan sawah sepenuhnya menjadi tanggung jawab pemodal/penggadai. ${ }^{17}$

Bagi hasil merupakan salah satu rencana saat ini dalam masalah perekonomian Islam dan merupakan komponen dari kerangka contoh pemerintahan Islam. Dalam hal pelaksanaan persekutuan bagi hasil ini benar-benar terjadi sebagaimana dicontohkan oleh Rasulullah SAW, maka tidak diragukan lagi akan berpengaruh besar pada bantuan sosial pemerintah, mengurangi pengangguran dan sekaligus mengurangi jumlah orang miskin dan membuat pemerataan dalam penyampaian upah. Dalam hal bantuan pemerintah dari masyarakat membangun, jelas mereka yang tak berdaya dalam segi ekonomi akan sedikit demi sedikit terpenuhi secara finansial. ${ }^{18}$

Berikut salah satu hasil wawancara penulis dengan salah satu tokoh agama di Desa Patampanua terkait akad dari sistem bagi keuntungan hasil gadai yang berlaku dikalangan orangorang di desa tersebut sebagai berikut:

"Pendapat saya terkait akad dari sistem bagi hasil gadai sawah yang dilakukan oleh masyarakat di desa ini bisa saja dilakukan, selama tidak melanggar syarat dan rukun

${ }^{17}$ Baharuddin "Sistem Gadai Sawah Pertanian dalam Presfektif Hukum Islam” Skripsi Fakultas Agama Islam Unasman (2012). h. 63

\footnotetext{
${ }^{18}$ Umrotul Khasanah,” Sistem Bagi Hasil Dalam Syariat Islam”, h. 127
} 
seperti adanya pemodal, pengelolah dan keuntungan serta tidak adanya pihak yang merasa dirugikan dari sitem bagi hasil tersebut". ${ }^{19}$

Menurut jumhur ahli fikih hukum Islam bahwa objek akad ditransaksikan, memerlukan komponen kesempurnaan adalah bahwa ia harus dibebaskan dari syarat fasid dan untuk kontrak dengan masalah itu harus dibebaskan dari riba. Secara garis besar ada empat alasan yang menjadikan fasid meskipun telah memenuhi rukun dan syarat terjadinya: (1) menyerah menyebabkan kerugian (2) gharar (3) syarat fasid (4) riba. Independensi dari keempat variabel tersebut merupakan syarat sahnya perjanjiankomponen kesempurnaan adalah bahwa ia harus dibebaskan dari syarat fasid dan untuk kontrak dengan masalah itu harus dibebaskan dari riba. Secara garis besar ada empat alasan yang menjadikan fasid meskipun telah memenuhi rukun dan syarat terjadinya: (1) menyerah menyebabkan kerugian (2) gharar (3) syarat fasid (4) riba. Independensi dari keempat variabel tersebut merupakan syarat sahnya perjanjian.

Dari hal diatas dapat diketahui bahwa selama akad bagi hasil gadai berjalan sesuai dengan rukun dan syarat dari bagi hasil itu sendiri maka bisa saja dilakukan dan tanpa merugikan pihak mana pun baik dari pihak penggadai maupun penggarap.

Bila dilihat dari segi akad bagi hasil gadai sawah antara penggadai dan penggarap yang ada di Desa Patampanua terdapat dua jenis yaitu sistem bagi hasil gadai sawah secara rata dan sistem bagi hasil gadai sawah dengan sistem satu banding dua (satu untuk penggadai dan dua untuk penggarap). Dari akad yang dilakukan oleh kalangan masyarakat di desa tersebut sudah sesuai dengan rukun dan syarat bagi hasil dimana ada kedua belah pihak yang bersepakat serta kesepakatan dibuat atas persetujuan oleh kedua belah pihak (penggadai dan penggarap) walaupun kesepakatan yang dibuat hanya sebatas lisan tanpa bukti hitam diatas putih.

Selain akad, masa perjanjian pun sangat penting dalam suatu transaksi khususnya dalam transaksi bagi hasil gadai. Berikut hasil wawancara penulis terkait dengan masa perjanjian bagi hasil keuntungan gadai sawah antara penggadai dan penggarap sebagai berikut:

"Mengenai berapa lama masa perjanjian bagi hasil gadai antara penggadai dan penggarap di desa ini tidak ditentukan. tapi perjanjian bagi hasil bisa berakhir bila masa gadaian si penggadai telah berakhir dengan pemilik lahan sawah tersebut, bisa juga berakhir bila si penggadai menggati penggarap sebelumnya dengan penggarap lain dan bila penggarap sudah tidak mampu untuk merawat lahan sawah gadaian si penggadai maka perjanjian antara penggadai dan penggarap pun bisa saja akan berakhir". ${ }^{20}$

Dari hasil wawancara penulis diatas maka dapat ditarik kesimpulan terkait masa perjanjian dari bagi hasil gadai sawah antara penggadai dan penggarap berakhir bila lahan sawah gadaian tidak lagi berada dalam kekuasaan penggadai atau diambil alih kembali sepenuhnya oleh pemilik lahan sawah tersebut dan masa perjanjian gadai pun bisa berakhir bila penggarap sudah tidak mampu untuk merawat lahan sawah gadaian dari penggadai.

\section{PENUTUP}

\section{A. Kesimpulan}

Berdasarkan penelitian yang telah penulis lakukan terkait pelaksaan sistem bagi hasil gadai sawah antara penggadai dan pengarap sawah di Desa Patampanua Kecamatan Matakali

${ }^{19}$ Rahaman, Toko Agama Desa Patampanua, Kec. Matakali Kab. Polman, Sulbar, Wawancara oleh penulis di Patampanua, 14 Mei 2021

${ }^{20}$ Sassul, Toko Agama Desa Patampanua, Kec. Matakali Kab. Polman, Sulbar, Wawancara oleh penulis di Patampanua, 14 Mei 2021 
Kabupaten Polewali Mandar terdapat dua sistem bagi hasil gadai yang terjadi di Desa Patampanua, yang pertama sistem bagi hasil gadai sawah dengan rata yaitu dengan menanggung bersama (penggadai dan penggarap) biaya selama masa perawatan lahan sawah tersebut dan setelah masa panen tiba maka hasilnya akan dibagi secara rata dan seadil-adilnya antara penggadai dan penggarap. Yang kedua sistem bagi hasil gadai sawah dengan cara satu banding dua (satu untuk penggadai dan dua untuk penggarap) dalam sistem bagi hasil ini penggaraplah yang akan menanggung segala biaya perawatan lahan sawah tersebut akan tetapi penggarap pula yang akan mendapat bagian yang lebih banyak .

Pandangan syariat Islam terkait sistem bagi hasil gadai sawah antara penggadai dan pengarap sawah yang terjadi di Desa Patampanua adalah boleh karena dalam proses akadnya tidak terdapat hal-hal yang fasid dan sistem bagi hasil gadai sawah yang dilukukan berjalan sesuai dengan konsep moral Islam dalam hal bagi hasil.

\section{B. Saran}

Tentang kesempurnaan eksplorasi penulis menyampaikan beberapa gagasan mengenai saran pembagian keuntungan gadai sawah antara Penggadai dan pengarap sawah di Desa Patampanua Kecamatan Matakali Kab. Polewali Mandar berikut ini dapat ditarik kesimpulan:

1. Bagi penggadai hendaknya lebih berhati-hati dalam menjalankan sistem bagi hasil agar sesuai dengan tuntunan ajaran Islam dan tidak mengutamakan keuntungan pribadi tanpa melihat kerja keras dari penggarap sawah gadaiannya untuk itu pembagian hasil panen antara penggadai dan penggarap haruslah di lakukan dengan seadil-adilnya.

2. Bagi penggarap agar dapat menjalankan tanggung jawab merawat lahan sawah dari penggadai dengan sebaik mungkin sehingga terciptalah kerja sama dalam hal bagi hasil yang baik tanpa adanya konflik.

3. Bagi seluruh masyarakat Desa Patampanua khususnya masyarakat yang melakukan sistem bagi hasil gadai yang sebaik mengetahui terlebih dahulu bagaimana sistem bagi hasil yang benar dalam Islam sehingga tidak melanggar ketentuan dari ajaran Islam dan tidak terjadi kekeliruan dalam proses pelaksanaan bagi hasil itu sendiri.

\section{DAFTAR PUSTAKA}

Abdul Ghofur Ansori, Gadai Syariah di Indonesia, Konsep, Implementasi dan Intitusional, Gadjah Madaa University PRESS, 2006

Ade Tri Cahyani, “Tinjauan Hukum Islam Terhadap Peraktik Gadai Pada Masyarakat Kecamatan Tapos Kota Depok", Kearsipan Fakultas Syariah dan Hukum UIN Syarif Hidayatullah Jakarta, 2015.

Ahmad Affan Ghafar," Pemanfaatan Barang Gadai Dalam Perjanjian Hutang Dibawah Tangan”, Jurnal Studi Kenotariatan, vol.12 no1 (2019).

Baharuddin "Sistem Gadai Sawah Pertanian dalam Presfektif Hukum Islam” Skripsi Fakultas Agama Islam Unasman (2012).

Harbani Pasolong, Metode Penelitian Administrasi Publik, (Bandung: Alfabeta, 2013).

Idri, Hadis Ekonomi, (Depok: Kencana, 2015).

Imam Suprayogo dan Tobroni, Metodologi Penelitian Sosial-Agama, (Bandung: Rosdakarya, 2001). 
Imamil Muttaqin," Perspektif Hukum Islam Terhadap Pelaksanaan Gadai Sawah Dalam Masyarakat Desa Dadapayam Kecamatan Suruh Kabupaten Semarang”, Kearsipan Fakultas Agama Islam Universitas Muhammadiyah Surakarta, 2015.

Mahmud'Abd. al-Rahman'Abd al-Mun'im, Mu'jam al-Musthalahat wa al-Alfazh al-Fiqhiyyah, juz II ( Kairo: Dar al-Fadhilah, 2008 M.)

Umrotul Khasanah," Sistem Bagi Hasil Dalam Syariat Islam”, Jurnal Hukum dan Syariah, vol 1 no.2 (2009). 